\title{
MODELS FOR MISSIONAL CHURCHES IN ACTS ${ }^{1}$
}

\author{
Johann du Plessis \\ Old \& New Testament \\ Stellenbosch University
}

\begin{abstract}
In the first part of the article the issue of identity is briefly defined and discussed. Several facets of the church's identity in Luke-Acts are identified as elements of a comparative grid. These are: the relationship with Jesus, inclusiveness, vulnerability vs. power, and movements of the Spirit. In the second and third parts the proposed grid is applied to the missional actions and communities in Luke and Acts respectively. The fourth part deals with a possible shift of paradigms from Luke to Acts and also within Acts itself. The paper closes with a few conclusions and gives indications for further investigation.
\end{abstract}

Key Words: Mission, Identity, Inclusiveness, Vulnerability, Holy Spirit, Luke-Acts

\section{Introduction}

Several existing missional models purport to be 'directly' derived from Luke-Acts, often to the exclusion of one another. I used the plural in the title of this paper (cf. 'models' and 'churches') because I hope to show that according to Acts, different 'programmes' and 'actors' were concurrently at work in the spreading of the Gospel. Although one can distinguish between the missional existence of the faith community and its missional programmes, I understand 'missionality' as being both of these at the same time. In other words: Missionality has its roots both in the identity and the actions of the faith community.

\section{The Issue of Identity - Developing a Grid}

Identity is often formed in comparison to other identities. The differences between the followers of Jesus and the Jewish synagogue, between the Jews and Gentiles, and between the church and Gentiles, become clear in the course of the narrative of Acts. Identity is named accordingly - two examples from Acts come to mind: The followers of Jesus were called 'people of the Way' in Jerusalem (9:2) and 'Christians' in Antioch (11:26).

The process of reconstructing characters from their narrated actions in the narrative involves a great deal of reader activity. Furthermore, identity has to cope with changes in the perception and functioning of authority over time. The changes in the way that society in general perceives and reacts to authority are well-documented. The shifting of the power balance in the Christian faith community, from being a Jewish splinter group to the gentile communities becoming the main exponents thereof, can be traced in the Acts narrative. It follows along the line of Peter's decline and Paul's rising and is accompanied by a simultaneous decline of the financial position of Jerusalem. I propose the following grid to discern the missional identity and actions of the faith communities in Luke and Acts:

This is a reworking of an introductory paper delivered at the launching of one of the sub groups at the Acts Conference in Stellenbosch in (2009). The introductory character is retained in this article. This article was also informed by papers read at two connected conferences in SA: the Acts conference (18-20 May 2009 in Stellenbosch) and a mini conference, "Missionary by its very nature" (24 March 2010 in Pretoria). 


\section{The Relationship with Jesus}

The relationship with Jesus (and its implications for the life style of his followers) is the primary element of the identity of the faith community. This relationship involves several aspects of association and dissociation including the following:

\section{- Conversion/Transformation}

Nida and Louw discuss several terms used in the New Testament to indicate a 'change in opinion concerning truth' (1988:373-376) and a 'change of behaviour' (1988:510-511). Terms used in Luke-Acts indicating this change of opinion and behaviour are: $\mu \varepsilon \tau \alpha v o \varepsilon ́ \omega-$ indicating a change of one's way of life as a result of a complete change of thought and attitude; the emphasis is usually on the complete change in thought and behaviour rather than fixating on the emotional component of sorrow or contrition (1988:510). The group

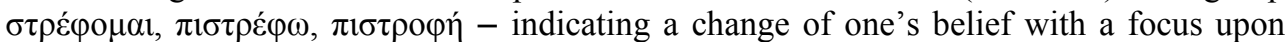
that to which one turns; the implication is that one turns toward God, i.e. to repent. The opposite, indicating that one no longer holds something or someone to be true or important,

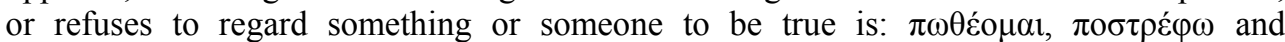
$\delta ı \alpha \sigma т \rho \varepsilon ́ \varphi \omega$. It can mean that someone is misleading others (e.g. in Luke Jesus is accused of misleading the people); another term indicating such behaviour is $\pi 0 \sigma \pi \alpha ́ \omega$ (as an accusation against Paul).

The quest of a Jesus-like life style introduces the issue of the 'holiness'. ${ }^{2}$ Holiness can be regarded as the validation of the claim to be associated with Jesus (i.e. conversion). Ethical and cultic 'rules' of conduct can either be implemented to empower people (i.e. inclusively, as by Jesus Himself), or to purify the community and safeguard it from 'unworthy' influences (i.e. exclusively, as by Jesus' opponents). In the case of Acts a study of the redactional notes reveals the general reception of and reaction to the gospel in the early faith communities seen from the narrator's perspective and it also specifies the conspicuous lifestyle and actions of the followers of Jesus.

\section{- Faith}

Nida and Louw (1988:376-379) discuss the semantic domains of 'trust and rely' with a special application in 'being a believer of the Christian faith'. It is clear that faith involves the question of allegiance and association vis-á-vis opposition and dissociation. On account of who Jesus is and what he did, the audience is regularly urged to repent and believe. Terms occurring in Luke-Acts are: the word group $\pi \imath \sigma \tau \varepsilon v ́ \omega / \pi i \sigma \tau \iota \varsigma / \pi \imath \sigma \tau$ ó $\varsigma$ usually indicates that someone believes the good news about Jesus and becomes His follower. Another term is $\pi \varepsilon^{\prime} \theta \omega$, indicating complete trust and reliance in something or someone. Luke-Acts also testifies about opponents who reject Jesus completely $(\theta \varepsilon \tau \varepsilon \dot{\varepsilon} \omega)$, or refuse to believe; some followers become apostate or temporarily lose the ability or willingness to believe and act

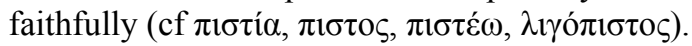

2 Cf Marshall in Holiness and Ecclesiology (2007):114 ff. - he focuses his study on the word group $\alpha \gamma 10 \varsigma$ in Acts and also includes the different notions of $\delta \mathrm{i \kappa} \alpha$ os. Prescriptions and taboos for table fellowship in early Mediterranean cultures and in Palestine, serves as a model for the study of Thompson (Holiness and ecclesiology (2007):76ff.) on holiness in Luke. 


\section{- Baptism and Eucharist}

Generally speaking it seems as if in Luke the emphasis is on meals, with relatively few references to baptism, whereas in Acts the focus seems to be on baptism, with relatively few references to meals and especially to the Lord's Supper. If this tendency is confirmed by the grid, it might be an indication of a paradigm shift between Luke and Acts. The Jewish communities were likewise distinguished by well defined, cultic rites and customs.

\section{- Salvation}

Nida and Louw (1988) discuss the different aspects of the 'profit' gained from being a

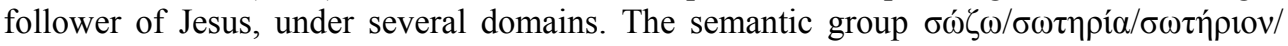
$\sigma \omega \tau \eta \dot{\rho} \rho$ refers to salvation in a religious sense and is a figurative extension of the meaning of either 'to rescue from physical danger' or 'to heal, to make whole' (1988:241). This context of healing can also be linked to 'magic'. Salvation is counterbalanced by God's judgement over the unbelieving opponents.

\section{Inclusiveness}

Inclusiveness involves more than just an open and inviting membership strategy. It implies transcending existing boundaries.

\section{Relations to and the wielding of Power}

The power of God becomes apparent in miracles, signs, exorcisms and miraculous rescues, as well as in the control of plot development in both narratives by the Holy Spirit. The term 'kingdom of God' is in itself empire terminology. There is a power struggle between the Jewish authorities (powers) and Jesus in Luke, and between the Roman and Jewish authorities and the church in Acts.

\section{The 'Movements' of the Spirit in the Faith Community and Society ${ }^{3}$}

The Holy Spirit, as the divine agency, acts as Executing Subject in both narratives: In Luke this focus is concentrated in the so-called Childhood Narrative (Luke 1-3) and the beginning of Jesus' ministry (the temptation scene). In Acts the Holy Spirit is instrumental in guiding the mission activity through miracles and signs, revelations and strategic interventions.

\section{Perspectives on the Missional Existence of the Faith Community from the Gospel of Luke - testing the Grid}

The Gospel of Luke is the primary element for a comparative study of Luke-Acts. The material accumulated in this section serves as a starting point for the definition of the missional identity and actions of the faith community.

\footnotetext{
For the third and fourth item in the proposed grid, I would like to draw attention to a forthcoming publication from Bybel Media that is part of the Acts project initiated by Communitas that started with a conference in Stellenbosch in 2009 and culminates in a third conference in Pretoria in 2011. It uses two main lenses to read parts of the Acts narrative, namely "movements of the Spirit" and "the vulnerability of the faith community". It remains to be seen what reception and effect it will have on the missional identities of congregations who use it.
} 
Jesus' programme of inclusion is the creative force

The universal trend in Lucan theology and Jesus' inclusive salvation programme has been extensively researched and are generally accepted. Jesus' comprehensive programme of inclusivity can be presented in the following semiotic square:
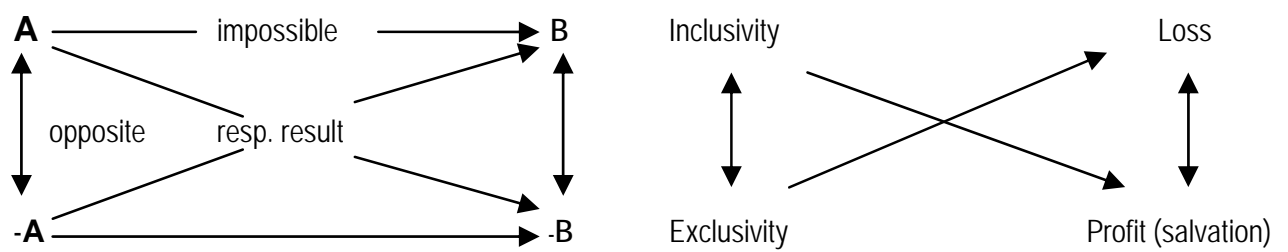

It is a comprehensive programme that includes association with members from all spheres of society (especially those who were deemed unworthy by society at large) and the transformation of instruments of exclusion in the hands of the Jewish elite (e.g. the keeping of the Torah), into instruments that enable those who were previously disadvantaged to become full members of the new community of Jesus followers (cf. the way Jesus reinterpreted and applied the Sabbath rules).

\section{Inclusiveness is per se already a challenge to the status quo}

In the highly stratified Early Mediterranean society of Luke-Acts, inclusivity poses a challenge to the surrounding society. Jesus' actions elicit a very negative response from his opponents who follow an exclusive programme. Inclusiveness is also a challenge within the faith community. Luke joins John in relating the quarrel among the disciples about who are the greatest as a part of the Passion Narrative (both Matthew and Mark have it earlier in their respective narratives). Thereby it is placed in stark contrast with the actions of Jesus who is about to be crucified.

\section{Jesus' inclusive Approach involves a Preferential Option for the Excluded and Powerless}

Jesus' preferential option for the poor and the destitute is a part of inclusiveness, but it is a special trait in Luke: e.g. the parables of the Good Samaritan (10:25ff.) and The Pharisee and the tax collector (18:9ff.), as well as Jesus' remarks on the poor widow's offering (21:1-4) addresses the issue of disparity. In Luke these boundaries that need to be crossed are mainly drawn within the Jewish society itself, focusing on ethical (moral), cultic and socio-economic parameters. Moral-ethical parameters include 'sinners, tax-collectors and sinful women'; Cultic parameters are clean vs. unclean, diseases (e.g. leprosy, menstrual problems and fever), epilepsy and psychiatric illness (i.e. possessed by evil spirits) - these were often regarded in ethical terms (i.e. seen as indicators or results of some or other sin); Socio-Economic parameters might be some occupations that were regarded as inferior (e.g. shepherds and fishermen), poverty (often had cultic implications; e.g. in the offerings and sacrifices that had to be given), gender and age (women and children were regarded as having less power in society) and geographical location. There are some exceptions such as the Samaritans $(9: 51-56 ; 10: 30-37 ; 17: 11-19)$, Roman officials $(7: 1-10 ; 23: 47)$ and other non-Jews $(4: 25-27 ; 8: 26 \mathrm{ff}$.$) , but in Luke the movement remains mainly within Jewish$ society. 


\section{Compassion and Association is the Essence of Salvation}

The emotive force for inclusivity is Jesus' compassion with the destitute. Nida and Louw (1998:295) discuss attitudes and emotions (cf. the word group $\sigma \pi \lambda \alpha \gamma \chi v i \zeta o \mu \alpha 1 / \sigma \pi \lambda \alpha \gamma_{\chi} \chi v \alpha$ ), as well as positive moral and ethical qualities such as goodness, gentleness, kindness and mercy in domain (88:743-751). The Sermon on the Plain is an obvious example of Luke's emphasis of compassion, whereas in Matthew's version of the Sermon on the Mount the conclusion with regard to the behaviour God expects reads, 'be perfect, as your heavenly Father is perfect' (5:48), the Lucan version is 'be merciful, just as your Father is merciful' (6:36 - both quotations from the NIV).

If the emotion driving Jesus' inclusive programme is compassion, one of the most powerful instruments realising it in the narrative, is table-fellowship. ${ }^{4}$ Jesus regularly dines with all kinds of people in Luke. At these meals disciples are taught, women are elevated, outsiders are included and opponents become more alienated. Salvation in Luke boils down to association by Jesus and with Jesus, and the opportunity for it often is a meal.

Baptism is the instrument of repentance and judgement in Luke: this is true of John the Baptist's practice (cf. Luke 3) and also of his interpretation of Jesus' imminent ministry (i.e. as a baptism by fire, 3:15-17). Jesus' own baptism (3:21-22) likely refers to his suffering later in the narrative, esp. in the light of the remark in 12:50 which clearly links the coming baptism with the passion. Baptizing of members of the Jesus community cannot be found in Luke.

\section{The Role of the Holy Spirit in Luke is mainly to lead}

As stated above, from a narrative point of view the Holy Spirit may be regarded as the Executing Subject of the story - more or less similar to a director calling the shots. Guidance in Luke is not solely by the Holy Spirit. ${ }^{5}$ Jesus is led/directed $(\gamma \omega)$ into the desert by the Spirit and there He fasted for 40 days $(4: 1-2)$. Prayer and fasting are usually joined, so this might be an instance where the Spirit directs Jesus to pray. Prayer occurs widely and at crucial points in Luke, often combined with Jesus' retiring to secluded places and against the backdrop of his spreading fame, but the Spirit does not instigate any of these prayers. An overview of the role of the Spirit regarding the identity of the faith community in Luke reveals the following: people are led by the Spirit - this is the case with the supporting characters in the Childhood Narratives (e.g. Elizabeth, Zachariah and Simeon). Jesus is led and empowered by the Spirit - it is clear that the Spirit is instrumental in the Temptation episode (4:1-2). ${ }^{6}$ The Spirit's descending upon Jesus at his baptism in the image of a dove (3:21-22) and the start of the Galilean ministry 'in the power of the Spirit' (4:14) indicate some form of empowerment. Finally people receive the Spirit - as an answer to prayer $(11: 13 ; 18: 1-8)$. The promised 'power' at the end of the narrative is identified as the Spirit in Acts, but in Luke the presence or the working of the Spirit is not a prominent characteristic of the faith community. The relationship with Jesus is paramount.

4 Table fellowship can be regarded as a type of scene that indicates the context where Jesus includes unexpected people and where opponents distance themselves from Jesus; cf. McMahan (1987), meals as type scenes in the gospel of Luke.

5 Cf the heavenly messengers sent to Zachariah and Mary (cf. 1:15-17; 1:35-37); the angel Gabriel is sent by

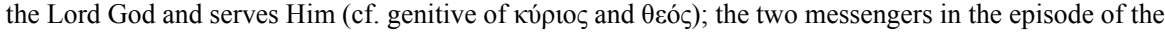
Transfiguration (9:28-36), Eliah and Moses, are likewise not directly linked to the Spirit.

6 It seems viable that Luke intended a focus upon Jesus' suffering by the arrangement of the temptations (the jumping off the temple in the prominent final place). 
The 'Mission Scenes' in Luke 9:1-6(+10) and 10:1-16(+17-24)

Luke is the only Synoptic Gospel presenting the reader with a double tradition about Jesus' sending of his disciples. ${ }^{7}$ The second rendering is more elaborate (the number of disciples is significantly higher and the orders are more detailed, and the outcomes more pronounced). The two episodes form a ring composition: it flanks a fair amount of material that deals with Jesus' identity, specifically the aspects of his glory and coming suffering. The repetition serves to accentuate the commission of the followers and its firm foundation in Jesus' own ministry.

\section{- Some Observations from the Second Episode (Luke 10)}

There is a close link between Jesus' glory and his suffering in the narrative block flanked by the two commissions. Jesus' identity involves both glory and suffering at the same time. The disciples' commission is intimately linked to the ministry of Jesus, which suggests a parallel outcome in their fate and identity, i.e. glory and suffering woven together! There is also an interplay between power and dependence regarding their mission: they have this extraordinary message and authority accompanied by powerful signs, blessings and curses, but at the same time they are quite vulnerable, similar to lambs among wolves; they are totally dependent upon the hospitality of those to whom they are sent, not allowed to take their own 'extras'; they are followers of one who made it clear that He is going to be killed. It is a very fragile and vulnerable existence.

\section{Case studies from Acts - applying the Grid}

\section{Communities as Characters ${ }^{8}$}

The initial image of the faith community is one of a relatively small and secluded group of Jesus followers in Jerusalem, with a strong Jewish expectancy about the future, cf. their inquiry about the 'kingdom of Israel' (1:6), whereas Jesus spoke about the 'kingdom of God' (1:3) and the crossing of boundaries (1:8). ${ }^{9}$ This image changes dramatically with the outpouring of the Spirit as the fulfilment of God's promise. The Coming of the Spirit (Ac 2) is a programmatic episode and functions as a type scene together with the other manifestation-episodes at crucial points in the narrative. The faith communities maintain a strong allegiance to the synagogue, but also form distinct groups that regularly gather for worship and community life.

In the course of the narrative several names, which indicate their relationship with Jesus, are given to these communities, e.g. the 'faithful', the 'disciples' or the 'congregation'. In Antioch they were called 'Christians' (11:26). The term 'brothers' indicates a fellowship. By outsiders (opponents and officials) they were called people of 'the Way' $(9: 2 ; 19: 23 ; 24: 14 \& 22)$.

\footnotetext{
Cf. Mark 6:7-13 (+30) and Matthew 10:1-11:1. The latter has an extended coverage of the events and includes most of the details of Luke 10 .

8 Thompson (2006) argued convincingly that the faith communities function as characters in the Acts narrative.

9 The early Jesus communities indeed regarded themselves as the real (new) Israel of God, but here the request seems to be consciously juxtaposed to Jesus' teaching in the introductory verses.
} 


\section{- Jerusalem}

The relationship with Jesus: The leadership of the early Jerusalem faith community consisted of characters carried forward from Luke (i.e. the disciples with Matthias in place of Judas). Added to them were a group of six leaders (Ac 6) of which only Stephen (Ac 7) and Philip (Ac 8) receive more than just a passing acknowledgement in the narrative. James, the brother of Jesus, who became a very influential leader of the church is also a leader. Membership started relatively small, but grew consistently (cf. 2:47; 6:1\&7; 9:31) through the audience's positive response to the gospel message and their amazement at miracles and signs. In several instances these conversions are followed by baptism. Regular redactional notes by the author give an indication of the high moral lifestyle of the church (2:43-47; 4:31-36) and the reception it received among the rest of society. Salvation is defined as the forgiveness of sins, the receiving of the Holy Spirit as a gift from God, salvation (it includes physical healing), the return of Jesus Christ, repentance (2:37-40; $3: 16 ; 3: 19-21 ; 4: 10-12 ; 5: 31-32)$. The opponents of the faith community and its members are the Council and Herod. There is a growing animosity from the side of the Council and their actions become bolder as the plot develops $(5: 18)$. There is dissidence within the faith community at a very early stage (cf. Ananias and Sapphira, 5:1-11) and also quarrels about the inclusion of non-Jews in the church (Ac 10-11); the latter leading to the so-called Jerusalem Council (Ac 15) to settle the dispute.

Inclusiveness: Crossing boundaries caused some problems for the Jerusalem faith community and because apostolic authority resided in Jerusalem it naturally had an effect on the way the gospel spread to surrounding areas (i.e. Judea, Galilee and Samaria). This becomes clear in the modus operandi whereby evangelization elsewhere had to be sanctioned from Jerusalem (in Samaria (8:14-17) and Antioch (11:22)). The spreading of the gospel generally shows exclusivist behaviour at first (11:19 - they told the message 'only to Jews'). This exclusivist approach was gradually transformed because of the persecution of the Jerusalem community after Stephen's death and because of instances where non-Jews responded positively to the message (e.g. the Samaritans, the Ethiopian eunuch, Cornelius and the community in Antioch). The outcome of the Jerusalem Council constitutes a movement toward real inclusivity. 'Bridge characters' enhancing the movement of the gospel into non-Jewish communities in the first part of Acts are: Greekspeaking (Hellenized) Jews who became converted to the Christian faith, Samaritans and the so-called 'God-fearers'.

Vulnerability (power issues): The Jerusalem church enjoyed clear precedence in terms of status and authority in the faith community throughout the Acts narrative. At the same time they suffered the onset of severe persecution and consequently a loss of leaders, possessions and numbers. ${ }^{10}$ Impoverishment led to the collection among churches outside of Palestine on behalf of the Jerusalem community (11:19-30). Another aspect of this dwindling of Jerusalem's power is the 'disappearance' of leaders like Peter, John, Stephen and Barnabas from the narrative. These signs of powerlessness are the primary instruments for the spreading of the gospel in Acts. It forces the faith community to move away from Jerusalem and its surroundings and opens up the space for other role players to take it to the ends of the earth.

10 The destruction of Jerusalem is not named as such in Acts, but would have had a profound impact on the Jewish segment of the faith community, especially in Jerusalem. 
Movements of the Spirit: The first part of Acts narrates three manifestations of the Spirit (probably linked to prayer), ${ }^{11}$ all accompanied by the phenomenon of speaking in tongues, as well as several other signs. These are: the initial outpouring of the Spirit (Ac 2) as the fulfilment of God's promise; the manifestation after a prayer when the community was severely threatened (Ac 4); and finally at Cornelius as a validation of the conversion of a Gentile (Ac 10 and Peter's references to it in 11:15-18 and 15:8-11). ${ }^{12}$ Other instances of the Spirit's activities are: the signs (miracles) validating the truth of the gospel message; the empowering of witnesses often in contexts of persecution $(2: 14 ; 4: 8 ; 7: 55)$; empowering of the faith community to stay steadfast in the faith; the guiding of the spreading of the message by the followers. In the latter case the shift in the direction of an inclusive paradigm becomes very clear (cf. Philip's excursions; Peter and Cornelius; the letter after the Jerusalem meeting).

\section{- Antioch}

Barnabas was sent to Antioch as an envoy from Jerusalem, he went to fetch Saul from Tarsus and they worked there for a year. Antioch in Syria, the home base for Paul (and Barnabas), is the only other faith community in Acts that consciously embarks on a programme to spread the gospel. These envoys consistently return to the sending community to report on events from the mission trips and to be dispatched again $(14: 26-28$; $15: 40 ; 18: 18-23)$.

Relationship with Jesus: Antioch is mentioned as the first place where the followers of Jesus were called 'Christians' (11:26) - a clear indication of the perceived connection between Jesus Christ and the community of followers. The city was a place of refuge for those who fled Jerusalem and Judea after the outbreak of severe persecution following the death of Stephen. The content of the message is that Jesus is kúpios and that people should convert to Him [to Him as Lord (11:20-23)]. This had highly subversive political implications in the light of the Emperor worship.

Inclusiveness: The first leaders at Antioch showed great diversity. ${ }^{13}$ The members were mainly Greek speaking Jews (11:19-20).

Vulnerability: It seems as if the community in Antioch was financially fairly strong and that the collection on behalf of Jerusalem originated there (11:29-30 and 12:25).

Movements of the Spirit: The Spirit was instrumental in the sending of Paul and Barnabas $(13: 2)$ and His guidance is closely linked to worship, fasting and prayer (13:2-3; 15:40).

I now proceed to material from the context of Paul's persecution and imprisonment (i.e. from the next part of the narrative that involves the so-called missionary journeys (Ac 13-20)). The events occur in several locations but I limit myself to three major cities: Philippi and Corinth (in Macedonia during the second journey) and Ephesus (in Asia during the third journey). The narrator's remarks about events and outcomes regarding the spreading of the gospel and the life of the faith communities continue in the second part of the narrative (cf. 15:36 which leads to $16: 4-5 ; 18: 23 ; 19: 20$ ). The Spirit is instrumental

11 In the case of Ac 4:31 clearly so, the others in the context of a gathering of followers in worship.

12 The events in Samaria (8:15ff.) may be regarded as another reference to manifestations of the Spirit but it is unclear what the specific characteristics were. The episode clearly demonstrates the aforementioned apostolic control exercised from Jerusalem and might be used as a rhetorical device.

13 They were Barnabas, Simon the Negro, Lucius (a Roman name), Manaen (a man who grew up with Herod) and Saul. 
(16:6-10) in the crossing of boundaries. The gospel is presented to all people and membership of the faith community consistently includes both Jews and Gentiles. Conflict develops between society (i.e. with Jews as well as Roman civil authorities) and the church in all the cities where the gospel is brought (16:20-21; 17:7-8; 17:19; 18:12-13).

\section{- Philippi (16:11-40)}

Relationship with Jesus: Lydia, a cloth dealer who previously accepted the Jewish faith, is identified as the first convert. The 'Lord' is instrumental in her acceptance of the gospel message (16:14-15) and she and her household are baptised. The next scene tells of a slave girl who was freed from an evil spirit "in the name of Jesus Christ" and the subsequent uprising instigated by her owners. The episode ends with the conversion of a prison warden and the baptism of his household. The central position of Jesus is emphasized: "Sirs, what must I do to be saved?" he asks; the answer, "Believe in the Lord Jesus, ${ }^{14}$ and you will be saved - you and your household" (16:30-31). The opponents in Ephesus are the owners of the slave girl and officials of the local government.

Inclusiveness is promoted by choosing the local washing place where there was also a place of prayer as the venue for their witnessing. It was readily accessible to the women of the area.

The apostles' vulnerability became clear in their mistreatment: they were assaulted and imprisoned as a result of mob violence instigated by the owners of the slave girl for their own economic reasons - a case of economic power play. The narrator uses a literary technique of juxtaposition in the prison scene to persuade the reader: Paul and Silas were suffering injustice, but they were singing hymns; God brings about salvation through an earthquake, but the warden is on the brink of committing suicide; ${ }^{15}$ finally the perpetrators and their agents become the ones who are afraid.

The Spirit is not mentioned but there is reference to an evil spirit that was cast out in the Name of Jesus (16:18). The clash between empires occurs on two levels: the first within the spiritual realm where God triumphs, and the second between the forces of the Roman Empire and the kingdom of God (16:20, 38-39). Although God is triumphant in both instances, the faith community itself remains vulnerable and powerless.

\section{- Corinth (18:1-17)}

Relationship to Jesus: Paul, Silas and Timothy spent a relatively long time - a year and six months - in Corinth (18:11). The focal point of the ministry in the city (18:5-8) was to persuade the Jews to accept that Jesus was indeed the Messiah (the Christ). In the course of their stay several supporters from a Jewish background joined the faith community. Among these were: Aquilla and Priscilla (their conversion is not mentioned specifically, but when they later accompanied Paul to Syria they were reckoned among the believers $(18: 18)$ ); Titius Justus, who was a 'god fearer'; Crispus, the leader of the synagogue, and his family, became converted and joined the faith community; apparently his successor, Sosthenes, also became a Christian (18:16-17). Many 'other' people in Corinth (presumably non-Jews, 18:4) converted and were baptized. The opponents of the church in Corinth were Jews.

Or: "Believe that Jesus is Lord".

15 Opposed to the way they themselves were treated, Paul calls out to the warden not to harm himself - it is a conscious imitation of Jesus' conduct in the gospel of Luke. 
They accused Paul of teaching things that were contradictory to the Torah. In spite of attempts to involve Roman officials in the dispute, the governor of the area refrained.

Inclusiveness: The relationship between the church and the synagogue emerges at several points in Acts - also in this episode (18:5-8). According to the pattern that develops in the course of the narrative it is clear that the inability/unwillingness of Israel (the Jews) to believe the message about Jesus opens the door for the Gentiles to be included. Statements in the speeches ${ }^{16}$ about the stubbornness of Israel to accept God's messenger identify this animosity as the fulfilling of Old Testament prophecy. Three times the break with the Jews seems final: from now on the Jews will be excluded $(13: 45-47 ; 18: 5-8 ; 28: 28)$, but the ministry to the Jews continues throughout the narrative.

The vulnerability of the faith community and the witnesses are sustained (cf. the assault on Sosthenes without any intervention from the law).

Movements of the Spirit: There is no reference to the Spirit as such in the episode, but Paul receives a vision from the 'Lord' to comfort and motivate him to continue the ministry $(18: 9-10)$.

\section{- Ephesus (19:1-40; 20:17-37)}

Paul's ministry in Ephesus lasted two years (19:10) of which three months were focused debates in the local synagogue (19:8). This is the final episode of Paul's missionary journeys before his journey to Jerusalem started. There are several allusions to previous scenes in Acts. The journey to Jerusalem is interrupted by a quick tour to Macedonia ${ }^{17}$ and the closing scene of this narrative block is Paul's address to the elders of Ephesus en route to Jerusalem (20:17-37). In a summarizing note the narrator states that the gospel message was inclusively directed to both Jews and Greeks (19:17-20). The success of the ministry evoked strong opposition from both groups, i.e. from the Jews (19:8-10) and the Gentile population (19:23-40)). As in Philippi the real motive behind the riot was economical (19:23-27). The Roman officials responded more positively than before: some are supportive of Paul (19:31) and the city clerk is able to quell the protest (19:35-40).

Jesus' position as the key figure of the Christian faith is central throughout the Ephesusepisode: Paul met some followers of John Baptist after arriving in Ephesus. They were aware of the One who was to come but didn't realize it was Jesus. Paul insists that it is only after accepting Him in faith and being baptised in his Name that the Holy Spirit can be received. His viewpoint is validated by a manifestation of the Spirit (19:5-7). ${ }^{18}$ Jesus' central position is again confirmed by the failure of some exorcists (the sons of Sceva) when they misused his Name for their own gain. ${ }^{19}$ Jesus is presented as the Originator of the gospel and Paul's ministry in his farewell address to the elders (20:21, "convert to God and believe in our Lord Jesus"; 24, "to finish the ministry I received from Jesus"; 28, watch over the church that was "bought by the blood of his own (Son)"). ${ }^{20}$

16 E.g. that of Peter $(2: 22-24 ; 3: 13-26 ; 4: 8-12 ; 5: 29-32 ; 10: 34-43)$, Stephen $(7: 51-53)$ and Paul (13:14-41; $24: 14-16 ; 26: 4-23)$,

17 This is in accordance with the final summarizing character of the Ephesus-episode. After this excursus the narrative proceeds to Jerusalem, to the trials of Paul, and ends in Rome.

18 The scene is reminiscent of the events at Cornelius' house.

19 Again reminiscent of an earlier episode: That of Anaias and Sapphira.

20 Cf. $\tau$ o díov - a genitive of origin. The reference is not to God's own blood - which is a foreign theological concept - but to the only Son of God. 
Vulnerability: in Ephesus Christians again became the target of mob violence (19:29). The issue of vulnerability though is especially prominent in Paul's closing address to the elders of Ephesus. There Paul expands on the suffering and hard work which are part and parcel of his ministry. It is a fixed part of the life of any follower of Jesus that he himself willingly accepts and he exhorts the elders to do the same (20:22-24, 29, 33-35, 36-37).

Regarding the movements of the Spirit, I have already referred to the fourth manifestation of the Spirit, which is closely linked to the laying on of hands and to baptism in the Name of Jesus. In the farewell speech the argument is Trinitarian, cf. references to Jesus $(20: 21$, $24,35)$, the Holy Spirit $(20: 22,28)^{21}$ and $\operatorname{God}(20: 21,24,28,32)$. The Holy Spirit is here presented as the Executing Subject, the Guide and Principal Employer of the apostle and the elders. The Trinitarian language links the Holy Spirit to the other Partners of the Trinity and might open the way to assign acts and modalities to the Spirit that have been elsewhere in Acts attributed to the 'Lord' or to 'God'.

\section{Human Agents}

Acts refer to several unnamed witnesses in the story of the gospel's progress. Several women play a prominent part in the narrative. None of the human characters is active throughout the narrative. They 'disappear' from the plot whether by death (Stephen and James) or by omission (e.g. Peter, Philip and Barnabas). Paul is a character that enters the narrative rather late, but stays on until the end. His conversion is narrated at length and twice interpreted in speeches. Paul progresses through several stages in the course of the narrative - from persecutor, to converted evangelist and pastor, eventually to being persecuted himself. He experiences the guidance of the Spirit in several ways. His own suffering is present from the outset at his calling. He is a staunch defender of inclusive practices and contracted a variety of enemies. Eventually he ends up in Rome where he teaches the gospel freely and without hindrance to anybody who visits him (cf. the juxtaposing empire terminology in Acts' final verses). The experience of individuals and communities indicate that suffering remains part and parcel of God's plan for salvation. The necessity and saving significance of Jesus' own suffering is reiterated, but the witnesses of the gospel themselves will also experience suffering.

\section{Is there Evidence of Shifting Paradigms?}

Counter-cultural movements in the church's history more often than not had a profound impact on mission. Jesus (in Luke) can be regarded as a highly a-typical male and the faith community following Him (in Acts) should also be counter-cultural in many respects. From the investigation above, the continuity between Luke and Acts seems to be intact, but there is a marked development, even shifting, in some of the characteristics and programmes between Luke and Acts, and within Acts. ${ }^{22}$

\section{Baptism and Conversion in Acts vs. inclusion at Meals in Luke}

The distinguishing marks for being a Jew are the practice of circumcision, maintaining and adhering to the Torah and celebration of Jewish festivals. In Luke the ways between Jesus

1 The remark refers back to 9:16 but it is anticipatory as well, cf. 21:10-14

22 Progression and development might be seen as an affirmation of the unity between the two narratives. If possible differences should, however, be regarded as irreconcilable, it can be an affirmation of the independence of the two narratives. 
and the Jewish leaders split on account of the interpretation and practices of the Sabbath, while on the other hand He maintains the regular meetings at synagogues and the celebration of festivals. Circumcision is no problem in Luke. It is only in the Acts narrative that the issue of circumcision became a bone of contention between Jewish and Gentile Christians. In Acts Christians continued to celebrate the annual festivals and the weekly Sabbath meetings. I have already mentioned the marked difference between Luke and Acts when comparing the material on meals and baptism respectively. The possible reasons for such a shift falls outside the scope of this article but it indicates a paradigm shift between Luke and Acts.

\section{Inclusiveness: The Crossing the Boundaries in Luke and Acts}

In Luke Jesus' opponents take offense because of his disregard for reigning sociological boundaries. Jesus frequently associates with those individuals and groups that existed on the periphery of society, i.e. tax collectors, sinners and lepers. Through table fellowship these outsiders are regarded as Jesus' friends and associates. The model of table fellowship is continued in Acts (cf. Finger, 2007). Luke focuses on the crossing of socio-economic and cultic boundaries within the Jewish community as such. Most of his disciples were from socio-economic minority groups in Palestine. This remains the case in the first part of Acts. With Paul's missionary journeys the fellowship is extended to include non-Jews. This is a clear development in the paradigm regarding inclusivity from Luke to Acts.

Apart from telling the story of outsiders who convert to becoming followers of Jesus, Acts also relates the process of the faith community's own 'conversion' to become really inclusive and cross-cultural. Bridge characters play an important role in this transformation.

\section{Changing Opponents and Supporters from Luke to Acts}

Jesus' opponents change between Luke and Acts. In Luke his enemies are the Jewish religious leaders - comprising of the Sadducees, the Pharisees, the scribes and leaders of the different synagogues. The crowds are generally regarded as the unaligned Jewish people that need to be persuaded to accept Jesus, but their support is fluctuating and often shortlived. This pattern continues in the earlier parts of Acts though the narrative seems to be more sympathetic to the Pharisees as a group and even note the conversion of a number of priests in Jerusalem (Acts 6:7). In the second part of Acts the opponents are still the Jews and their leaders, but non-Jewish opposition becomes more accentuated. ${ }^{23}$ Jesus' main $^{\prime}$ supporters also change between Luke and Acts moving from a group of predominantly Jewish peasants to socio-economically varied, cross-cultural groups all over the Roman Empire, comprising of both Jews and Gentiles simultaneously.

\section{Development in the Definition of Salvation within Acts}

A study of the speeches in Acts reveals fixed formulations of the contents of the faith. Two elements, the death of Jesus and his resurrection, form the backbone of the confession. Though different elaborations might be added in different episodes, Jesus is identified as the Messiah through his death and resurrection. The saving significance of Jesus' death and resurrection is currently the theme of a lively debate. ${ }^{24}$ This does not mean that the signify-

23 It indeed becomes a clash between two countervailing "empires" - cf. the article of Prof Jeremy Punt "Countervailing 'missionary' forces: Empire and Church in Acts" elsewhere in this edition of Scriptura.

24 E.g. Rego (Suffering and salvation (2006)) discusses the sacrifice metaphor extensively and Heim (Saved from sacrifice (2006)) suggests an alternative to the well-known sacrificial theology of Anselm. 
cance of Jesus' death and resurrection should be limited to atonement alone. In Luke-Acts one does not find Paul's well-developed atonement theology, it is more a question of salvation through association. ${ }^{25}$ The process of the restoration of relationships between previously opposing groups and individuals is also part of the dynamics of salvation in Luke-Acts. Conflicts, however, are not necessarily resolved instantly (cf. the quarrel between Barnabas and Paul in Acts 15:39-41). Another aspect of salvation is the understanding of Jesus' resurrection. It is a recurrent theme in the speeches in Acts. There seems to be a development in the course of the narrative that culminates in Paul's defence in Athens and continues onward, namely that Jesus' resurrection facilitates a general resurrection of the dead. This is an indication of a paradigm shift within the Acts.

\section{Issues regarding Vulnerability and Power: from Dependence to Self-providing}

Suffering is a focal point in both narratives. Apart from manifestations in powerful deeds and words, both narratives relate that guidance by the Spirit is linked to suffering. According to Luke-Acts the Spirit leads Jesus and the church consciously on a path of suffering. In the clash of different empires, ${ }^{26}$ vulnerability/ powerlessness is the mode for the existence and actions of the church. The masses, consisting of mainly powerless individuals, represents the audience who needs to be persuaded to follow Jesus. They exhibit an impressive collective power: sometimes their support prevents Jesus' and the church's opponents to move against them, and on other occasions through their lack of support they become instigators or at least partakers in the violence. This again accentuates the defencelessness of Jesus' followers all the more. In Acts at least four themes have a bearing on this powerlessness: The speeches in Acts serve as one of the main vehicles to spread the gospel and a significant number of these occur in contexts of persecution and/or imprisonment. One can add the non-permanence of several main characters in the story. The balance of power within the church itself shifts from the Jewish sector (Jerusalem) to the Hellenistic world, both in numbers and socio-economic status. Persecution played a pivotal role in this shift. Finally, there is the well-developed theme of Paul's suffering (similar to Jesus in Luke) under the specific guidance of the Holy Spirit.

There is a subtle change in paradigm between Luke and Acts: Luke emphasises the dependence of the missionaries on the audience, whereas the mission programme in Acts changes to self-sufficient or base-supported efforts (i.e. to avoid burdening receiving communities). The congregation in Antioch's programme, as well as Paul's practice of 'tent making', are examples of this development.

\section{Movements of the Spirit}

Prayer remains a focal point in Acts, but the role of the Holy Spirit in the life of the faith community - both overtly and covertly - is expanded in comparison to Luke. Unlike in Luke the Spirit seems to be directly linked to the disciples' suffering in Acts.

25 The $\pi \dot{\varepsilon} \rho$-formula in Luke 22:20 indicates that Jesus' death is beneficial, without necessarily implying that it is sacrificial.

26 The Emperor cult is not named explicitly, but should nevertheless be taken into account when dealing with empire issues in Acts. 


\section{Conclusions and Further Study}

The Quest for an 'ideal'/primary Model in the View of the Narrator

It became clear that there is no such indication. The developments rather point in the direction of multiple, contextually determined programmes for mission. One should therefore envisage co-existing models for missional existence; complementing instead of competing. ${ }^{27}$

\section{The Missional Identity of Faith Communities}

It remains to be seen what the impact of the three conferences on the missional identity of churches in SA will be. The current difficulty to attain a general acceptance of the confession of Belhar revolves around issues of identity, specifically powerplay versus vulnerability which often disregards the missionary nature of Belhar.

\section{BIBLIOGRAPHY}

Bosch, DA 1991. Transforming mission: Paradigm shifts in theology of mission. New York: Orbis.

Brower, KE and Johnson, A (ed.) 2007. Holiness and ecclesiology in the New Testament. Grand Rapids: Eerdmans.

Brümmer, V 2005. Atonement, Christology and the Trinity. Making sense of Christian doctrine. Hampshire: Ashgate.

Dollar, H 1996. St. Luke's missiology: A cross-cultural challenge. Pasadena: Carey.

Du Plessis, IJ 1995. Die evangelie volgens Lukas. Dele I-III. Kommentaar op die Nuwe Testament: Struktuur - Uitleg - Boodskap. Kaapstad: Lux verbi.

Du Plessis, J et al (ed.) 2009. Missionary perspectives in the New Testament. Pictures from chosen New Testament literature. Wellington: BybelMedia.

Finger, R Halteman 2007. Of widows and meals. Communal meals in the book of Acts. Grand Rapids: Eerdmans.

Heim, SM 2006. Saved from sacrifice: a theology of the cross. Grand Rapids: Eerdmans.

Louw, JP and Nida, EA (ed.) 1988. Greek-English lexicon of the New Testament based on semantic domains. Vol 1 \& 2. New York: UBS.

McMahan, CT 1991. Meals as type-scenes in the gospel of Luke. UMI.

Matson, DL 1996. 'Household conversion narratives in Acts. Pattern and interpretation'. Journal for the study of the New Testament. Supp. Series 123. Sheffield: Academic Press.

McKnight, S and Jones, T 2007. A community called atonement. Volume 1 of Living theology. Abingdon Press.

Olivier, B 2005. 'Wanneer die tyd uit lit is: Aktivisme of apatie?' in Fragmente. Tydskrif vir filosofie en kultuurkritiek No. 14/15.

\footnotetext{
27 Many such models exist, e.g. Schreiter (2005) - mission as reconciliation; Rieger (2004) - investigates the current developments between neo-colonialism and post-colonialism, and precisely because of internal colonialism pleads for an understanding of mission as "in reach" (as a supplement to "outreach" and "relationships"); Bosch (1993) - mission is also a quest for justice.
} 
Rego, A 2006. Suffering and salvation: the salvivic meaning of suffering in the later theology of Edward Schillebeeckx. Louvain: Peeters Press.

Schreiter, RJ 1992. Reconciliation: mission and ministry in a changing world order. New York: Orbis.

Thompson, RP 2006. Keeping the church in its place: The church as narrative character in Acts. New York: TT Clark.

Van Staden, P 1991. 'Compassion - the essence of life. A social-scientific study of the religious symbolic universe reflected in the ideology/theology of Luke.' HTS Supplementum 4. 